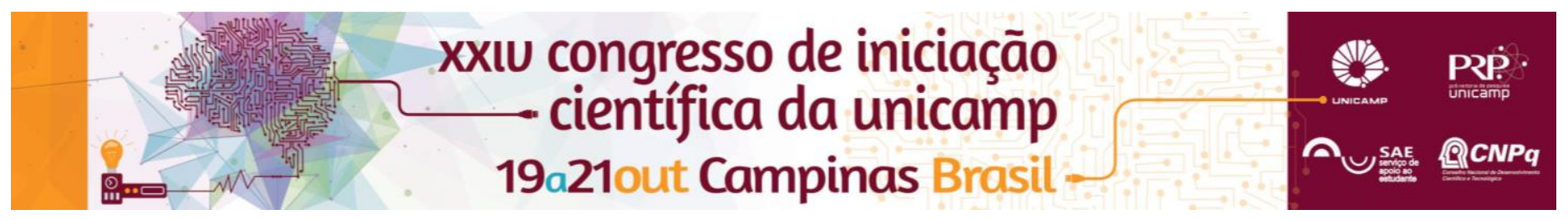

\title{
Formação Básica em Produção Sonora
}

\section{Katarine Barbosa Fernandes*, Maycon Nascimenteo de Sousa*, Raimundo Nonato da Cunha Lopes*, orientador: Prof. Dr. José Eduardo Ribeiro de Paiva}

\section{Resumo}

O projeto tem como objetivo capacitar o aluno às tecnicas básicas de produção sonora, da roteirização à finalização do material. Através de leituras e treinamentos específicos, os alunos se familiarizam com as questões e procedimentos da produção sonora, realizando como produto final, um audio documentário.

\section{Palavras-chave:}

produção sonora, rádio documentário, gravação sonora

\section{Introdução}

O projeto se inicia com leituras e treinamentos técnicos básicos de gravação sonora. A partir disto, trabalhamos sobre duas fontes distintas: de um lado, se realiza o treinamento técnico, e de outro, se levanta o material que será objeto do audiodocumentário a ser produzido. O documentário é realizado a partir da escolha dos alunos sobre temas que os mesmos levantam, e que são discutidos nas suas escolas de origem.

A partir desta escolha, o material é roteirizado, as locuções e as entrevistas de campo são gravadas pelos participantes do grupo e se iniciam os trabalhos técnicos de gravação, edição e mixagem.

Uma das etapas principais é a escolha das falas das entrevistas de campo que serão utilizadas, e sua articulação com as locuções e trilha musical gravadas em estúdio, procurando com isto uma dinâmica própria do meio sonoro. Os alunos também se alternam em todas as funções, como locução, gravação, mixagem e finalização.

\section{Resultados e Discussão}

Foram produzidos dois áudiodocumentários: "preconceito musical " e "o mosquito da dengue e a saúde pública no Brasil. O material realizado tem boa qualidade técnica e traz discussões atuais e necessárias para questões de cidadania e saúde.
Fig. 1 Tela do softare pro tools utilizado no processo.

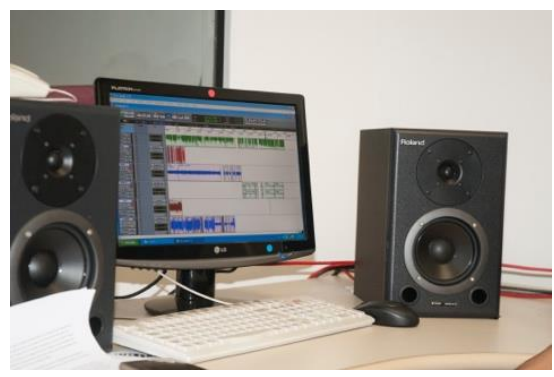

fig.2 Grupo de alunos no estúdio

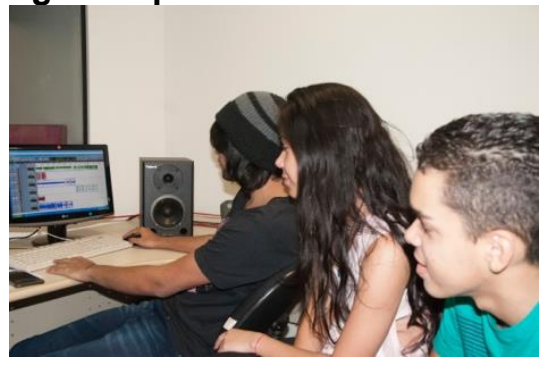

\section{Conclusões}

Foi uma experiência interessante que capacitou os alunos à produção sonora, em todas as suas etapas e dificuldades. Além disto, resultou em dois materiais produzidos em sua totalidade.

\section{Agradecimentos}

Estúdio de Multimeios - Departamenento de Multimeios, Mídia e Comunicação - Institututo de Artes $\mathrm{CNPq}$ 